\title{
Aftermath of Social Rights and Environmental Issues on Global Market: The African Experience
}

\author{
Abiola Esther Ogunmokun \\ Bucharest University of Economic Studies, Bucharest, Romania \\ abiolaogunmokun@yahoo.com
}

Received date: 28 August 2017; Accepted date: 24 November 2017; Published date: 7 February 2018

Academic Editor: Adam Ryszko

Copyright (C) 2018. Abiola Esther Ogunmokun . Distributed under Creative Commons CC-BY 4.0

\begin{abstract}
An avenue in which interrelationship exists among economic regions is through trade. In order to encourage and promote exchanges across national boundaries, measures are put in place for economic resources to be productively and successfully utilized. These measures that entail prerequisites' producers may be inquired to meet which relates to a wide range of sustainability metrics, respect for basic human rights, worker health and safety, the environmental impacts of production, community relations, land use planning and others. The impact of these measures on producers which led to social and environmental issues in global market is what this study tends to focus on. More so, the effect of these measures on commercial relations amongst economies is what makes this study considered as a topic of interest. Comparative analysis will be used to examine and highlight the impact of these measures on international business. Encroachment of social rights and environmental degradation are profoundly established in present day industrial revolutions. However, large-scale industrialization, besides its unquestionable benefits, triggered a systematic assault against human dignity and environmental health. The ensuing expansion of world trade further worsened the consequences. More so, environmental and social issues may manifest in diverse ways, thereby affecting operations in worldwide market and also limiting the number of participants in global market.
\end{abstract}

Keywords: International market, social and environmental issues.

Cite this Article as: Abiola Esther Ogunmokun (2018), " Aftermath of Social Rights and Environmental Issues on Global Market: The African Experience", Journal of South African Business Research, Vol. 2018 (2018), Article ID 573888, DOI: 10.5171/2018.573888 


\section{Introduction}

Of a truth, trade relationships amongst countries are inevitable because some countries have absolute advantage in some resources while others have absolute disadvantage. As a result of this, commercial relations will exist among economic regions which give rise to regulations, measures and policies to promote exchange or trade among countries. The effect of these measures in international market is what this paper tends to focus on. However, social and environmental issues have got entangled in international trade since the beginning of industrialization, which triggered a boom in the international flow of goods and services. McKenzie, Lionel W. (1954) mentioned that exchange of capital, goods and services among governments or individuals creates an avenue for specialization and brings about increase in a country's capacity to produce goods and render services. This portrays the significance of foreign trade in an economy because it also makes it possible for countries to have access to goods and services over which it has absolute or comparative disadvantage. Also international trade is beneficial to the economy because it promotes increased efficiency and greater wealth among trading nations. Despite the significance of international trade, the growing tendency of economies to operate across national boundaries is presented with challenges which can be detrimental to economic growth and development. The challenges come into play in the area of measures or standards placed on international trade that is most times difficult to comply with by producers (mostly from less developed regions). Most of these measures emerged in developed economies to deal with sustainability problems driven by production issues and to improve the quality of products sourced from different countries.

Also, as a result of human activity, changes occurred in the environment that led to environmental degradation. These environmental issues bring about changes which can be temporal or permanent to the atmosphere, water or land thereby causing pollution. More so, to collect export earnings nations would relentlessly boost export production, most often overlooking the serious harm they were inflicting upon the environment and human rights which may be either reversible or irreversible. Though, social issues may have an effect on the surrounding communities, but the extent of social and environmental impacts depends on the industry sector and can be categorized into low risk, medium risk or high risk. The effects of standards implemented by the economies which brought about the social and environmental issues are what this study will focus on. This standard implies a generally accepted behavior in a society and a guideline that regulates the effect of human activity upon the environment. Standards are placed by countries to protect or promote trade and growth. The international market is subject to regulations made by governments in "home" and "host" countries.

Countries adopt strategies to promote domestic trade against foreign competition or as a way to avoid it been used as a dumping ground by some countries who export inferior or substandard and harmful products. These countries use some of these forms; - tariffs "taxes imposed on imported goods which make them expensive and less competitive relative to goods produced domestically", subsidies "transfer payments given by governments to domestic suppliers of goods and services to increase production and make domestically produced goods more competitive". Quotas "it is a limit on the amount of goods that can be imported in a given period". These measures limit imports into a country by protecting commercial activities within that country against foreign competition as mentioned by Jones, Ronald W. (1961). On the other hand, protectionism as a strategy mostly proves to be counterproductive because it creates a 
reaction whereby other countries engage in their own protection policy thereby leading to high cost of goods and services. More so, an act of protectionism creates short term gains at the expense of substantial long term gains. The outcome of these trade barriers is that they lead to increase in cost of goods and this becomes unaffordable or too expensive for citizens in less developed or developing regions that rely on this trade from their meager income. It is against this background the effect of social and environmental issues in international market is considered as a topic of interest. As such, this study is further sub-divided into four sections. Section two reviews literature pertinent to this study while section three covers standards in international market. Section four will cover the effects of social and environmental issues and some challenges faced by African exporters in their attempt to enter the international market while section five concludes the study.

\section{Literature Review}

Daniels, J. et al (2007) mentioned that due to the world economy that has become global in scope, there is exchange amongst countries which leads to market expansion due to commercial transactions like investments, sales, transportation, private, logistics and governmental that occurs between two or more regions beyond their political boundaries. In as much as these commercial relations are beneficial, they are faced with some obstacles. For instance, to trade in international market, producers or manufacturers are increasingly required to adopt standards before they are able to showcase their products through export. More so, a producer may even be excluded from international value chains if he fails to comply with the set standards. A producer's inclusion in a sustainable value chain fosters better environmental and social practices and can improve financial outcomes for participating producers as mentioned by von Hagen and Alvarez (2011). The effect of this exclusion for less developed or developing regions will be the inability to attain sustainable growth and reduce chronic poverty failing their interaction and integration with the rest of the world, which obviously entails making strong efforts to comply with the social and environmental policies as mentioned by Oluwasola (2014). There are variations in the standards operating in countries which impact their accessibility and these differences may have a significant impact on producers especially small and medium scale enterprises (SMEs) and small farmers. A number of studies also found mixed evidence on the net income for producers and some even found a negative impact on net income for producers. This was the case where the increased earnings did not compensate for the additional costs and increased labour involved in complying with standards' provisions as mentioned by Jaffee (2008). However, the overall impact of standards is not always entirely visible when donors or non-governmental organizations (NGOs) temporarily cover certification costs. Lastly, there is a risk that increased supply of certified products may create increased competition to find buyers. Nebel et al.,(2005) mentioned that oversupply may lead to certified products being traded without being distinguished from noncertified products, resulting in diminishing or eliminated premiums. On the other hand, business related positive effect can outweigh direct financial impact of standards; business conditions like guaranteed sales for certified produce, better relationships with buyers, increased yields and enhanced quality.

\section{Standards in International trade}

Social and environmental standards have increasingly become the tool of choice in international value chains, covering agricultural products, electronics and services. Standards first emerged in developed countries, but a growing number of new standards are now being created by developing countries. These standards emerged as a market instrument to tackle multiple sustainability issues that cannot be resolved through compliance with national 
legislation and compulsory market requirements. Standards used in international business can be set by nongovernmental organizations (NGOs), private enterprises and consortiums of companies. However, the number of available standards is much higher in larger and richer countries where there is an increased demand for certified products. However, major worldwide brands have coordinated their manageable sourcing responsibilities into their corporate techniques. Although, many studies have explored the nature of these standards and their effects on various stakeholders but no large scale empirical evidence is available on how accessible and user friendly these standards are for producers.

More so, the new economic order has two aspects: on the one hand, formerly poor countries from the South have managed to carve out industrial apparatuses of their own, thereby reducing their dependence on imports from the North, especially in terms of processed goods like machinery, chemicals etc. This is doubtlessly a good thing. While on the other hand, their export production is, to a great extent, destined to developed countries' markets. The latter (with the EU as the flagship) have embarked upon a farreaching program aimed at stopping environmental degradation and social rights infringement, imperatively requesting that goods and services be sold in the respective countries' markets, whether domestically produced or imported, conform to a set of social and environmental standards. Consequently, a host of exporting firms from developing countries (and not solely) that used to export their goods on western markets or wish to do it in the future, are now making great efforts to comply with these standards. Based on the fact that these standards are hard to surmount an obstacle, such standards are viewed not as a necessity but rather as a surrogate for non-tariff barriers on imports and therefore hinted at as veiled protectionism.
Subsequently, the exports of agricultural products operate within a political, social and legal guideline. The most significant principles in any system are those characterizing, allotting and authorizing property rights, guidelines and conventions defining suitable and non-suitable forms of cooperation and competition (measures, tenets of agreements etc.). Frameworks in regards to property rights are essential. Rights to utilize, trade and change resources are fundamental to market improvement, since this assigns to individuals the privilege to advantages and disadvantages in production and marketing activities. Standards indicating entry conditions and limits on agreeable and aggressive strategies likewise encourage international trade. Standards set up and enforced can reduce exchange cost by expanding accessible information to buyers and consumers. These standards can include basic weights, measures, quality evaluation and contract forms.

Why are social and environmental standards hard to comply with? They are hard to comply with because such standards differ a great deal from the common standards that have been used in international trade as barriers against imports. Moreover, governments often arbitrarily impose irrelevant, even useless standards, on purely protectionist purposes. By contrast, social and environmental standards are both relevant and necessary but they are hard to fulfill by exporters because they entail large investments as well as production and distribution chains restructuring and ultimately serious governmental involvement. Surely, this often surpasses poor countries' possibilities.

\section{Social Rights and Environmental Issues}

This focuses on why social rights and environmental issues emerge in international trade. Exportation of products with high environmental impacts may bring about pollution in the economy that imports such products. As a whole, international exchange 
among countries leads to increase in world output which implies that the total volume of pollution and environmental degradation is likely to increase. Environmental effects of trade could be direct or indirect. More so, international trade environmental effects may also be beneficial. This arises through the spread of environmentally friendly technology, more efficient production which tends to reduce materials and energy use per unit of output. Based on social rights and environmental issues, trading nations may come under pressure to improve environmental standards when products quality or trans-boundary impacts are at issue. The social and environmental standards are a thorny issue because they requires the convergence of national policies in the field (mutual acceptance or recognition), even the inclusion of interregional agreements. The EU is on the front lines to defend environmental health and social rights observance. As mentioned by Kishlanski et al (1995), the relationship between environment and international trade is an indirect one: it goes through the industrial development process that began in the West two hundred years ago. Industrial activity has been acting as a threat to the environment continuously ever since. However, these environmental issues center around;-Property rights (patents, trademarks), taxation, institutional environment within which the global marketer must operate, movement of equity and expropriation threats that often necessitate signing of trade frame working agreements and so on.

Provisions were made for protecting the environment and conserving resources by international trade agreements. Nations are permitted in World Trade Organization (WTO) to take into account the ecological effects of items, but not those associated with production process. This has prompted various trade disagreements about whether particular measures are defended on the grounds of security of life and wellbeing, or are essentially masked protectionism. Efforts to regulate the international legal system include individual country efforts e.g. USA, international Trade Commission and the GATT system. The GATT system is a set of norms and procedures acceptable by member governments to create order and predictability in international trade relations. Countries that got industrialized at an early age also became great exporters of the goods and services they produced thereby triggering a boom in the international flow of goods and services. As mentioned by the United Nations (2005), the ceaseless increase in export production has been inflicting pernicious effects upon environment health and human rights, which were nevertheless long overlooked. Yearly, S. (1995) mentioned that developing countries' industrialization, which was much delayed, chiefly unfolding after the $2^{\text {nd }}$ world war, further compounded the harm to the environment. Since industrialization in the developing world generally embraced the highest polluting industries, (coal and steel, textiles, etc.) pollution eventually spanned the Planet.

Trade issues get reactions at various levels; national, regional or international. To promote trade, institutions for transnational environmental standards were set up by the European Union. Also, an environmental monitoring authority was established by the North American Free Trade Agreement but it has little control. Global ecological issues are addressed by the Multilateral Environmental Agreements (MEAs). However, propositions have been made for a World Environmental Organization to administer worldwide ecological approach, and to fill in as a supporter for natural interests in global trade. In situations of ineffective environmental policies at the provincial or worldwide level, national approaches are expected to address any trade related environmental issues. More so, labeling and certification requirements established by nongovernmental organizations (NGOs) or governments can go a long way in promoting international trade in areas of corporate practices and consumer awareness. 


\section{Effects of social and environmental issues in international market: African Experience}

Considering the fact that interrelationship exists among economies through trade which is seen as a means of sustainability for most less developed regions; these economies would always want to be involved in global market. Trade amongst economies leads to market expansion thereby improving total welfare and consumer choice. These environmental policies do provide opportunities in the area of redirection to "green" innovation and productivity growth in which most advanced firms gain while others loose. It also aims at protecting human health and the environment. Even though international trade has been recognized as been valuable based on the propositions that there will be trade flows among or between participating countries, if gains are possible, this is often not the case in reality. These policies bring about various hindrances to some key exports, especially those in which some developing countries and particularly Africa have a comparative advantage, which restricts trade flows. Jabati et al, (2013) mentioned that as a result of these trade obstructions, African nations have found it difficult to take full advantage of the opportunities embedded in international trade. African economies are enriched with agricultural products and over $50 \%$ of the world trade comes from developing countries and these economies depend on these key exports for sustaining their economy. As such, special and differential treatment provisions call for consideration of the needs of less developed or developing regions when establishing and implementing these measures. The effect of these measures or policies on exports from less developed regions is that they lead to:-

$>$ Lengthy and unfair bans on some products from Africa.

$>$ Application of measures to ban exports without sufficient scientific evidence.
$>$ Inability of some exporters to participate in the international market due to prohibition or restriction of their products which denies them access to developed market.

$>$ Decrease or hindrance to economic growth of less developed regions which depend solely on these exports for sustainability.

$>$ Exclusion from the market due to the inability to meet up with the measures or policies.

$>$ Increased energy prices or non availability of some certain products. They also affect the availability and price of certain products because of increased tax or ban as a result of their effect on human health or the environment.

Subsequently, developed regions have many advantages over the less developed regions in internal and foreign markets because they have adequate facilities and access to technology. These facilities make it possible to test quality and safety of products. This enables developed regions to set high standards for imports which are difficult or impossible for less developed economies to meet. In the long run, the effect of these measures on exports from these economies is that they hinder their capacity to show case their products and participate in the international market which in turn has a negative effect on the economic growth and development of these economies. Social and environmental issues also affect the number of participating economies in the international market thereby leading to reduction in global trade transactions.

\section{Africa's Export in International Market}

As at the year 2016, the world's total export of goods and services was estimated at $17,018,115$ million US dollars of which the top 5 countries (United States of America, China, Germany, Japan, and France) account for $44.46 \%$ of it. According to WTO (2017) 
statistical review, merchandise trade by region 2015-2016 illustrates Africa's participation in the global market. Developing economies recorded a decline in the share of merchandise exports from 43.4(2015) to 42.4(2016). Also in its participation in world merchandise trade, there was a slight decrease in 2016 to $42 \%$ of world exports and $40 \%$ of world imports. Developing economies in Asia happen to account for the largest share of developing economies trade in the world $28 \%$ of total world exports and $25 \%$ of total world imports) followed by developing economies of Latin America. Africa recorded a slight decline in trade in 2016 and accounts for $2.2 \%$ of the total world exports and $3.2 \%$ of the total world imports. This shows that it is importing more than it is exporting which is not healthy for the economy. To attain economy growth, there is a need for increased exports. Africa accounts for a small fraction $(2.2 \%$ in 2016$)$ of the global exports of merchandise trade. This analysis shows that Africa is not having full access to developed market because its percentage share in global trade is too little. Africa's participation in international market (in terms of export) can be hindered by its inability to meet up with social and environmental standards in international market and any other factor. As such, there is a need for an increased participation of Africa in global market because it will go a long way in boosting the economy and pave the way for attaining economic sustainability in these regions.

\section{Challenges Faced By African Exporters in Their Attempt to Enter International Market}

Export is of great significance to an economy because to an extent it influences the growth of the economy. Exchange by economies in the global market brings about expansion if goods thereby increasing consumer choice. Also because some countries are better at producing some goods than the others, there is a need for trade relationships among countries. As much as African exporters want to be fully involved in the global market, they are faced with some stumbling blocks which limit their level of participation. Some of these challenges are;-

1. Inadequate scientific and technical infrastructures which makes it difficult to meet up with measures set in international market

2. Lack of financial or technical resources to implement stringent requirements.

3. Insufficient awareness and misapplication of regulations.

4. Poor communication and networking within and between countries.

5. Frequent changes in the importing countries requirements; compliance in the new food laws and requirements of importing countries.

6. Lack of capacity to mitigate against unfair trade barriers.

7. Lack of an effective monitoring control and surveillance system.

8. Tax policies.

9. High cost of doing business.

More so, African producers especially SMEs are often poorly informed and may not possess the technical knowledge or have access to modern technologies necessary to implement social and environmental standards. These limitations can make it very difficult for them to compete in global markets. For instance, about 22 percent of all Nigeria's exports go to Europe and these accounts for 25 percent of Nigeria's trade. These possibilities are limped by such a large number of imperatives including high cost of doing business, inadequate infrastructures, lack of standardization, and unfavorable international trade rules and practices.

\section{Conclusion}

Of a truth, international transaction is needed among countries, thereby creating 
room for market expansion across the territory. More so, these trade transactions amongst countries have a multiplier effect on a nation's growth and development which leads to an increased involvement in international business. Although, the aim of this policy is to improve the individual wellbeing and the environmental sustainability of the economy; but it met unusual strong resistance by stakeholders who are faced with challenges in the market. The world seems to be hardly prepared for an outright battle for containment of environment deterioration. Though certain developing countries are making some headway but the capacity of firms to comply with technical regulations is at the present time, limited. However, for an effective quality and safety assurance system, there is a need for capacity building, and improvement in scientific and technical infrastructures of the less developed economies.

Environment protection involves administrative efforts, no-negligible expenditures and not least, determined political will. Governments must get involved by providing industries with information, guidance, and infrastructure in the field. The EU's new legislation in the field is in fact a starting block that will surely trigger emulation among countries and regions in the long run. Yet in the short run, the EU's rules are a challenge for its trade partners that must comply with them or otherwise risk been excluded from the single market. Such an outcome would be disastrous for many developing countries, whose dependence on the single market is vital.

Also, as efforts to encourage free trade, the European Union aims to play a key role in keeping markets open worldwide and helping Europe to exit from the economic crisis. The European Union trade policy is working to; create a global system for fair and open trade which reflects and respects the needs and concerns of developing countries, open up markets with key partner countries, ensure trade is a force for sustainable development etc. In addition, a more effective policy that tackles new economic realities is being proposed. This new policy tagged "trade for all" is a new trade and investment strategy that will make trade agreements more effective at delivering new economic opportunities in Europe. With this, we could conclude that liberal trade is of great significance to economic growth and development of less developed regions because it brings about increased savings and investment which has a multiplier effect on the nation's growth.

\section{References}

\section{AfDB, OECD and UNDP (2015) African Economic Outlook 2015: Regional Development and spatial inclusion}

2. Daniels, J.,Radebaugh, L., Villarreal, D. (2007). International Business: environment and operations. $11^{\text {th }}$ edition, Prentice Hall. ISBN 0-13-186942-6

3. Frank, A.G. (2015) The Development of Underdevelopment, in Roberts, T., Hite, A.B. and Chorev, N. (eds.) The Globalization and Development Reader: Perspectives on Development and Global Change (John Wiley and Sons, Ltd.)

4. Jabati, M.C. (2003) Market access for developing countries of Africa: the reality, AGSF Occasional Paper No. 1, United Nations Food and Agriculture Organization, Rome

5. Jones, Ronald W. (1961). "Comparative Advantage and the Theory of Tariffs". The Review of Economic Studies

6. Kishlanski, M., Geary, P. și O’Brien, P. (1995) Civilization in the West, $2^{\text {nd }}$ ed. Harper Collins College Publisher

7. Kogan, R.A. (2012) REACH Revisited: A frame work for evaluating whether a nontariff measure has matured into an actionable non-tariff barrier to trade, American University International Law Review 28 
8. McKenzie, Lionel W. (1954). "Specialization and Efficiency in World Production", The Review of Economic Studies.

9. Michida, E. (2014) The Policy Impact of Product-Related Environmental Regulations in Asia, The Institute of Developing Economies, Discussion Paper nr. 451

10. Oluwasola, O. (2014) Environmental pollution is inevitable in developing countries. Breaking energy, http://breakingenergy.com/2014/09/23/en vironmental-pollution-is-inevitable-indeveloping-countries/)

11. Oyeshola Dokun, O.P. (2008), Sustainable Development - Issues and challenges for Nigeria.

12. Stiglitz, J. E., Charlton A. (2005) Fair Trade for All: How Trade Can Promote Development, Oxford University Press
13. United Nations (2005) Environment and Trade: A Handbook, United Nations Environment Programme, International Institute for Sustainable Development

14. von Hagen, O and Alvarez, G. (2011), The Impacts of Private Standards on Producers in Developing Countries. Retrieved from http://www.intracen.org/The-Impacts-ofPrivate-Standards-on-Producers-inDeveloping-Countries/

15.WTO (2017), World Trade Statistical Review [Retrieved September 25, 2017], https://www.wto.org/english/res_e/statis_e /wts2017_e/wts17_toc_e.htm

15. Yearly, S. (1995) Dirty connections: transnational pollution, in Allen, J. and Hamnett, C. (eds.) A Shrinking World? Global Unevenness and Inequality (Oxford University Press). 